\title{
Exploring the endocrine activity of air pollutants associated with unconventional oil and gas extraction
}

\author{
Ashley L. Bolden ${ }^{1 *} \mathbb{B}$, Kim Schultz ${ }^{1}$, Katherine E. Pelch ${ }^{1}$ and Carol F. Kwiatkowski ${ }^{1,2,3}$
}

\begin{abstract}
Background: In the last decade unconventional oil and gas (UOG) extraction has rapidly proliferated throughout the United States (US) and the world. This occurred largely because of the development of directional drilling and hydraulic fracturing which allows access to fossil fuels from geologic formations that were previously not cost effective to pursue. This process is known to use greater than 1,000 chemicals such as solvents, surfactants, detergents, and biocides. In addition, a complex mixture of chemicals, including heavy metals, naturally-occurring radioactive chemicals, and organic compounds are released from the formations and can enter air and water. Compounds associated with UOG activity have been linked to adverse reproductive and developmental outcomes in humans and laboratory animal models, which is possibly due to the presence of endocrine active chemicals.

Methods: Using systematic methods, electronic searches of PubMed and Web of Science were conducted to identify studies that measured chemicals in air near sites of UOG activity. Records were screened by title and abstract, relevant articles then underwent full text review, and data were extracted from the studies. A list of chemicals detected near UOG sites was generated. Then, the potential endocrine activity of the most frequently detected chemicals was explored via searches of literature from PubMed.
\end{abstract}

Results: Evaluation of 48 studies that sampled air near sites of UOG activity identified 106 chemicals detected in two or more studies. Ethane, benzene and n-pentane were the top three most frequently detected. Twenty-one chemicals have been shown to have endocrine activity including estrogenic and androgenic activity and the ability to alter steroidogenesis. Literature also suggested that some of the air pollutants may affect reproduction, development, and neurophysiological function, all endpoints which can be modulated by hormones. These chemicals included aromatics (i.e., benzene, toluene, ethylbenzene, and xylene), several polycyclic aromatic hydrocarbons, and mercury.

Conclusion: These results provide a basis for prioritizing future primary studies regarding the endocrine disrupting properties of UOG air pollutants, including exposure research in wildlife and humans. Further, we recommend systematic reviews of the health impacts of exposure to specific chemicals, and comprehensive environmental sampling of a broader array of chemicals.

Keywords: Endocrine disruption, Unconventional oil and gas, Hydraulic fracturing, Fracking, Air pollutants, Reproduction, Neurological, Developmental, Hormone

\footnotetext{
* Correspondence: ashleybolden@tedx.org

${ }^{1}$ The Endocrine Disruption Exchange (TEDX), www.TEDX.org, Eckert,

Colorado, USA

Full list of author information is available at the end of the article
} 


\section{Background}

Advanced techniques used to develop oil and gas resources, including horizontal drilling and hydraulic fracturing (fracking), have unlocked fossil fuels from formations previously unavailable for extraction, including shale and tight sands. Research has found that unconventional oil and gas (UOG) development and production is associated with air pollution [1-7], contamination of surface, ground, and drinking water [8-10], as well as soil and sediment contamination [11-13]. Contaminants released from UOG sites enter the air readily during well pad development and continue for the life of the well, impacting both local and regional air quality. Industry wide there are hundreds of different products composed of a mixture of chemicals used during drilling, fracturing, and the cleaning and maintenance of well pads and equipment. Many of them are volatile and include several known carcinogens and hazardous air pollutants (HAPs) listed under the Clean Air Act [14]. Air pollutants are released both from the products and mobile and stationary equipment commonly used during UOG operations $[6,15,16]$. Further, unprocessed natural gas contains many volatile compounds that surface with methane and are released to the environment through venting and flaring and through fugitive emissions from well pipe fittings and equipment [6,16-18]. Additionally, open evaporation pits that contain fracking fluids that return to the surface (flowback) and water produced from fracturing the formation (produced water) further impact air quality in these areas [19-21]. Due to the potential for wide-spread exposure to air pollutants released from UOG activity and the growing number of oil and gas wells being drilled in close proximity to neighborhoods, including schools and recreational areas, the health of nearby communities may be at risk. Indeed, several studies have shown that UOG activity may adversely impact the health of humans and animals [22-26] and the environment [27-29].

These concerns have led to a growth in epidemiologic research with many studies suggesting a link between UOG proximity and adverse health impacts. Selfreported symptoms by Pennsylvania residents living near UOG operations in the Marcellus Shale include impacts to the upper respiratory system, irritation of the skin and sensory organs, and increased headaches [25, 30]. Additional studies also considered well activity or density, a method used to estimate exposure to air pollutants. McKenzie et al., found an increased risk of neurological and respiratory effects, blood disorders, and adverse developmental outcomes in Colorado residents living within one-half mile of natural gas wells [31]. These observations were more pronounced during well completion activities [31]. Increased odds of asthma exacerbations [32], nasal irritation, migraine headaches, and fatigue symptoms were more often reported by residents living near sites with higher UOG activity compared to a control population [33]. Risk of childhood hematologic cancer was also increased with increased density of UOG wells [34]. Further, retrospective cohort studies have linked UOG activity to adverse reproductive and developmental outcomes, such as preterm birth [35, 36], low birth weight [37], congenital anomalies [38], and infant mortality [36, 39]. These outcomes suggest a possible relationship between maternal exposure to endocrine disrupting chemicals and birth outcomes; however, results across studies are mixed.

In addition to epidemiological studies, recent studies using in vitro and experimental animal models to assess the connection between UOG activity and endocrinerelated outcomes have been published. In these initial studies chemicals detected in water collected near UOG operations such as spill sites and surface water near wastewater injection sites were shown to have activity in estrogen, androgen, progesterone, glucocorticoid, and thyroid hormone in vitro receptor assays [10, 40]. In laboratory experiments exposure has resulted in similar impacts across several different models. Specifically, male rodents exposed prenatally to a mixture of chemicals used during hydraulic fracturing were shown to have increased organ weights of the testes and thymus, decreased sperm counts, and increased serum testosterone levels [41]. Effects in female rodents included hormone suppression, changes in uterine, ovary, heart, and body weights, and disrupted folliculogenesis [42]. Emerging research in zebrafish embryos found that exposure to flowback/produced water from UOG increased embryo deformations and mortality, reduced metabolic rates, and altered cardio-respiratory gene expression [43, 44]. Further, embryonically exposed juveniles demonstrated decreased metabolic rates and fitness as judged by swim performance [45]. In exposed juvenile rainbow trout mRNA expression was elevated for several genes including vitellogenin and estrogen receptor alpha 2. Additionally, expression of oxidative stress and biotranformation genes in the liver and gills was observed [46]. Finally, exposure of Daphnia to flowback/produced water resulted in decreased reproduction and altered gene expression [47].

The purpose of this evaluation was to employ systematic screening-level methods to begin to prioritize air pollutants associated with UOG that have evidence of endocrine activity. This work could be used to identify avenues for primary research to understand endocrine disrupting properties of air pollutants; provide the groundwork for in-depth reviews of the health impacts of exposure to specific chemicals (i.e., systematic or scoping reviews); offer rationale for further exposure research in wildlife and humans; and lastly, identify research gaps. Specifically, two objectives were completed; 1) identification of the most commonly detected chemicals in the air near UOG activity, as reported in original 
research, and 2) to determine if this subset of air pollutants has been shown to have endocrine activity or have effects that could be linked to disrupted endocrine signaling.

\section{Methods}

Identification of air pollutants near sites of UOG activity Comprehensive literature searches were performed in order to identify studies that measured compounds in air near or on sites of UOG development in the United States (US). We used Web of Science and PubMed to complete electronic searches for all years to June 2016 . The search logic was developed using terms for major geologic formations in the US where UOG activity occurs and terms that linked the formations to air emissions (Additional file 1: Table S1). The titles and abstracts of these articles were then screened for relevance using Distiller $\mathrm{SR}^{\circ}$ [48] by two independent reviewers. For inclusion, studies had to present primary findings, be in the English language, and measure air pollutants near sites of UOG production. Studies that only measured methane were excluded. Discrepancies regarding inclusion were discussed and resolved by the two reviewers. Summary level data from relevant studies were collected. Parameters included publication date, chemicals detected, and the location of measurement. These data were used to develop the list of compounds detected in air. This initial list was then used to yield a list of the chemicals detected in greater than 10 UOG air sampling studies.

\section{Determination of endocrine activity of UOG related air pollutants}

The list of air pollutants associated with UOG production ascertained from peer-reviewed literature was crossreferenced with the Endocrine Disruption Exchange (TEDX) List of Potential Endocrine Disruptors (http:// endocrinedisruption.org/interactive-tools/tedx-list-of-potentialendocrine-disruptors/search-the-tedx-list: accessed October 2016) to determine if any of the chemicals had been characterized as having endocrine activity [49]. The TEDX List of Potential Endocrine Disruptors is a database that contains expert verified citations illustrating evidence of endocrine disruptive properties of a variety of chemicals; this database is continually updated as new evidence about chemicals becomes available [49]. Crossreferencing yielded the initial list of chemicals with evidence of endocrine activity. For this initial list, citations from the TEDX List of Potential Endocrine Disruptors were used as evidence of endocrine activity. We then performed searches in PubMed using the chemical name and CAS number for the remaining chemicals detected in greater than 10 UOG air sampling studies to determine whether or not those chemicals had evidence documented in the peer-reviewed literature regarding their potential endocrine activity (for the individual chemical search terms see Additional file 1: Table S2). The following 15 chemicals were searched in PubMed: ethane, n-pentane, propane, n-butane, isopentane, isobutane, $\mathrm{m}, \mathrm{p}$-xylene, o-xylene, ethylene, methylcyclohexane, n-heptane, acetylene, n-octane, propylene, and cyclohexane. The PubMed records were imported into Sciome Workbench for Interactive computer-Facilitated Text-mining (SWIFT)-Review [50] and filtered using search terms (modified from $[51,52]$ ) intended to identify articles that assessed the endocrine activity of the compounds (see Additional file 1: Table S3). Though xylenes (the isomeric mixture) is listed on the TEDX List of Potential Endocrine Disruptors we performed searches for the compounds as represented in the air sampling studies (i.e., m,p-xylene and o-xylene). In addition, studies that evaluated the effects of exposure to $\mathrm{m}$-xylene and $\mathrm{p}$-xylene separately and citations from the TEDX List of Potential Endocrine Disruptors that assessed the xylenes were included.

\section{Results}

Our search of the literature from PubMed and Web of Science yielded 1366 and 2907 potential records, respectively (including any duplicate records). Screening of titles and abstracts by two reviewers identified 97 relevant articles. Full text review of the articles yielded 43 inclusions and 54 exclusions (30 duplicates, five that did not assess specific chemicals, 10 reviews, four conference abstracts, and five categorized as other [e.g., methods development]). In addition, hand searching yielded five other studies that met inclusion criteria, resulting in a total of 48 included studies.

Table 1 lists the 48 citations of the articles that measured air pollutants on or near sites of UOG production. A distribution of the studies measuring UOG air pollutants in sites across the US is shown in Fig. 1. The majority of studies were done on the Barnett Shale in Texas (11 studies). The least studied were Eagle Ford Shale in Texas, Haynesville Shale in Louisiana, Arkansas, and Texas, Fayetteville Shale in Arkansas, and Powder River Basin in Montana and Wyoming, all with only one study each. One hundred six chemicals were detected in two or more of the 48 studies that measured air pollutants near UOG sites and another 115 were detected only once (see Additional file 1: Table S4 for full list of detected chemicals). These chemicals represented a variety of classes including alkanes, alkenes, alkynes, aromatics, aldehydes and polycyclic aromatic hydrocarbons (PAHs). Twenty chemicals were detected in 10 or more studies with ethane and benzene being the most detected, appearing in $56 \%$ and $54 \%$ of studies, respectively. Fifty-four 
Table 1 List of citations for UOG air papers

Author Title

Brantley, HL. et al., 2015 [70]

Colborn, T. et al., 2014 [1]

Eapi, GR. et al., 2014 [71]

Eisele, AP. et al., 2016 [72]

Esswein, EJ. et al., 2014 [73]

Field, RA. et al., 2015 [20]

Field, RA. et al., 2015 [74]

Gilman, JB. et al., 2013 [2]

Goetz, JD. et al., 2015 [75]

Helmig, D. et al., 2014 [3]

Katzenstein, AS. et al., 2003 [76]

Koss, AR. et al., 2015 [77]

Lan, X. et al., 2015 [78]

Lee, L. et al., 2015 [79]

Li, C. et al., 2016 [80]

Li, R. et al., 2014 [81]

Lyman, S. and Tran, T., 2015 [82]

Macey, GP. et al., 2014 [4]

McKenzie, LM. et al., 2012 [31]

\section{thle}

Assessment of volatile organic compound and hazardous air pollutant emissions from oil and natural gas well pads using mobile remote and on-site direct measurements

An exploratory study of air quality near natural gas operations

Mobile measurement of methane and hydrogen sulfide at natural gas production site fence lines in the Texas Barnett Shale

Volatile organic compounds at two oil and natural gas production well pads in Colorado and Texas using passive samplers

Evaluation of some potential chemical exposure risks during flowback operations in unconventional oil and gas extraction: Preliminary results

Influence of oil and gas field operations on spatial and temporal distributions of atmospheric non-methane hydrocarbons and their effect on ozone formation in winter

Distributions of air pollutants associated with oil and natural gas development measured in the Upper Green River Basin of Wyoming

Source signature of volatile organic compounds from oil and natural gas operations in northeastern Colorado

Atmospheric emission characterization of Marcellus Shale natural gas development sites

Highly elevated atmospheric levels of volatile organic compounds in the Uintah Basin, Utah

Extensive regional atmospheric hydrocarbon pollution in the southwestern United States

Photochemical aging of volatile organic compounds associated with oil and natural gas extraction in the Uintah Basin, UT, during a wintertime ozone formation event

Atmospheric Mercury in the Barnett Shale Area, Texas: Implications for emissions from oil and gas processing

Particulate organic nitrates observed in an oil and natural gas production region during wintertime

Satellite observation of pollutant emissions from gas flaring activities near the Arctic

Measurements of hydrogen sulfide $(\mathrm{H} 2 \mathrm{~S})$ using PTR-MS: Calibration, humidity dependence, inter-comparison and results from field studies in an oil and gas production region

Inversion structure and winter ozone distribution in the Uintah Basin, Utah, USA

Air concentrations of volatile compounds near oil and gas production: a community-based exploratory study

Human health risk assessment of air emissions from development of unconventional natural gas resources
Sampling Location (Geologic Formation)

Denver-Julesburg

Piceance

Barnett

Barnett; Denver-Julesburg

Denver-Julesburg; Green River; Piceance

Green River

Green River

Denver-Julesburg

Marcellus

Uintah

Not reported

Uintah

Barnett

Uintah

Bakken

Uintah

Uintah

Denver-Julesburg; Fayetteville; Green River; Marcellus; Powder River; Utica

Piceance 
Table 1 List of citations for UOG air papers (Continued)

\begin{tabular}{lll}
\hline Author & Title & Sampling Location (Geologic Formation) \\
\hline Olaguer, EP. et al., 2015 [83] & $\begin{array}{l}\text { Updated methods for assessing the impacts } \\
\text { of nearby gas drilling and production on } \\
\text { neighborhood air quality and human health }\end{array}$ & Eagle Ford
\end{tabular}

Oltmans, S. et al., 2014 [84]

Omara, M. et al., 2016 [85]

Paulik, LB. et al., 2016 [59]

Peischl, J. et al., 2015 [86]

Pekney, NJ. et al., 2014 [87]

Petron, G. et al., 2012 [88]

Petron, G. et al., 2014 [89]

Prenni, AJ. et al., 2016 [90]

Rappengluck, B. et al., 2014 [5]

Rich, A. et al., 2014 [16]

Rich, AL. and Orimoloye, HT., 2016 [91]

Roscioli, JR. et al., 2015 [15]

Rutter, AP. et al., 2015 [92]

Schnell, RC. et al., 2009 [93]

Schwarz, JP. et al., 2015 [94]

Smith, ML. et al., 2015 [95]

Swarthout, RF. et al., 2013 [96]

Swarthout, RF. et al., 2015 [97]
Anatomy of wintertime ozone associated with oil and natural gas extraction activity in Wyoming and Utah

Methane emissions from conventional and unconventional natural gas production sites in the Marcellus Shale basin

Emissions of polycyclic aromatic hydrocarbons from natural gas extraction into air

Quantifying atmospheric methane emissions from oil and natural gas production in the Bakken Shale region of North Dakota

Measurement of atmospheric pollutants associated with oil and natural gas exploration and production activity in Pennsylvania's Allegheny National Forest

Hydrocarbon emissions characterization in the Colorado Front Range: A pilot study

A new look at methane and nonmethane hydrocarbon emissions from oil and natural gas operations in the Colorado DenverJulesburg Basin

Oil and gas impacts on air quality in federal lands in the Bakken region: An overview of the Bakken Air Quality Study and first results

Strong wintertime ozone events in the Upper Green River basin, Wyoming

An exploratory study of air emissions associated with shale gas development and production in the Barnett Shale

Elevated atmospheric levels of benzene and benzene-related compounds from unconventional shale extraction and processing: Human health concern for residential communities

Measurements of methane emissions from natural gas gathering facilities and processing plants: Measurement methods

Sources of air pollution in a region of oil and gas exploration downwind of a large city

Rapid photochemical production of ozone at high concentrations in a rural site during winter

Black carbon emissions from the Bakken oil and gas development region

Airborne ethane observations in the Barnett Shale: Quantification of ethane flux and attribution of methane emissions

Volatile organic compound distributions during the NACHTT campaign at the Boulder Atmospheric Observatory: Influence of urban and natural gas sources

Impact of Marcellus Shale natural gas development in southwest Pennsylvania on volatile organic compound emissions and regional air quality
Green River; Uintah

Marcellus

Utica

Fayetteville; Haynesville; Marcellus

Marcellus

Denver-Julesburg

Denver-Julesburg

Bakken

Green River

Barnett

Barnett

Not reported

Barnett

Green River

Bakken

Barnett

Denver-Julesburg

Marcellus 
Table 1 List of citations for UOG air papers (Continued)

\begin{tabular}{|c|c|c|}
\hline Author & Title & Sampling Location (Geologic Formation) \\
\hline Thompson, CR. et al., 2014 [98] & $\begin{array}{l}\text { Influence of oil and gas emissions on ambient } \\
\text { atmospheric non-methane hydrocarbons in } \\
\text { residential areas of Northeastern Colorado }\end{array}$ & Denver-Julesburg \\
\hline Townsend-Small, A. et al., 2015 [99] & $\begin{array}{l}\text { Integrating source apportionment tracers into } \\
\text { a bottom-up inventory of methane emissions } \\
\text { in the Barnett Shale hydraulic fracturing } \\
\text { region }\end{array}$ & Barnett \\
\hline Vinciguerra, T. et al., 2015 [100] & $\begin{array}{l}\text { Regional air quality impacts of hydraulic } \\
\text { fracturing and shale natural gas activity: } \\
\text { Evidence from ambient VOC observations }\end{array}$ & Marcellus \\
\hline Warneke, C. et al., 2014 [6] & $\begin{array}{l}\text { Volatile organic compound emissions from } \\
\text { the oil and natural gas industry in the Uintah } \\
\text { Basin, Utah: Oil and gas well pad emissions } \\
\text { compared to ambient air composition }\end{array}$ & Uintah \\
\hline Warneke, C. et al., 2015 [101] & $\begin{array}{l}\text { PTR-QMS versus PTR-TOF comparison in a re- } \\
\text { gion with oil and natural gas extraction indus- } \\
\text { try in the Uintah Basin in } 2013\end{array}$ & Uintah \\
\hline Weyant, CL. et al., 2016 [102] & $\begin{array}{l}\text { Black carbon emissions from associated } \\
\text { natural gas flaring }\end{array}$ & Bakken \\
\hline Yacovitch, TI. et al., 2015 [103] & $\begin{array}{l}\text { Mobile laboratory observations of methane } \\
\text { emissions in the Barnett Shale region }\end{array}$ & Barnett \\
\hline Yuan, B. et al., 2015 [104] & $\begin{array}{l}\text { Airborne flux measurements of methane and } \\
\text { volatile organic compounds over the } \\
\text { Haynesville and Marcellus Shale gas } \\
\text { production regions }\end{array}$ & Haynesville; Marcellus \\
\hline Zavala-Araiza, D. et al., 2014 [105] & $\begin{array}{l}\text { Atmospheric hydrocarbon emissions and } \\
\text { concentrations in the Barnett Shale natural } \\
\text { gas production region }\end{array}$ & Barnett \\
\hline Zielinska, B. et al., 2014 [7] & $\begin{array}{l}\text { Impact of emissions from natural gas } \\
\text { production facilities on ambient air quality in } \\
\text { the Barnett Shale area: A pilot study }\end{array}$ & Barnett \\
\hline
\end{tabular}

chemicals were detected in 3-9 studies and 147 were detected in 2 or fewer.

The list of chemicals detected near UOG activity was cross-referenced with the TEDX List of Potential Endocrine Disruptors. Twenty-six were already identified and listed in the TEDX List of Potential Endocrine Disruptors [49]. There were 15 additional chemicals that were reported as being detected in 10 or more UOG studies, but that were not currently included in the TEDX List of Potential Endocrine Disruptors that were searched. A chemical's absence on the TEDX List of Potential Endocrine Disruptors does not necessarily mean there is no evidence for endocrine activity. Rather, it is possible that the literature available for that chemical has not yet been investigated for endocrine activity. The searches of PubMed for the 15 frequently detected chemicals yielded eight with evidence from the literature indicating at least one study had shown the chemicals to be endocrine active (including findings related to potential endocrine activity). Those chemicals were m-xylene, p-xylene, oxylene, methylcyclohexane, n-heptane, isopentane, propane, propylene. There were no studies that evaluated the endocrine activity of ethane, n-butane, isobutane, ethylene, cyclohexane and acetylene found in our searches. In studies identified by our search that assessed the effects of n-pentane [53] and n-octane [54] endocrine activity was not shown. Table 2 characterizes possible endocrine activities for the individual chemicals. The studies listed in this table tested more direct indicators of endocrine activity such as estrogenic, androgenic, thyroidogenic, progestrogenic, glucocorticodogenic, and steroidogenic activities. In Table 3, chemicals identified as having evidence of physiological activity that may be linked to endocrine disruption are shown. This includes evaluations of reproduction, aryl hydrocarbon signaling, development, neurophysiology, and other endocrine related effects. Notably, a few of these air pollutants (e.g., benzene, n-hexane, and isopentane) may impact less commonly evaluated endocrine related endpoints such as insulin signaling and adrenal physiology (see Table 3). Roughly half of the chemicals in Tables 2 and 3 are PAHs, although it should be noted that few studies detected PAHs near UOG (see Fig. 2). Single ring aromatics such as benzene, toluene, ethylbenzene, xylene, and styrene are also shown in Tables 2 and 3 with evidence suggesting possible estrogenic, androgenic, reproductive, and developmental 


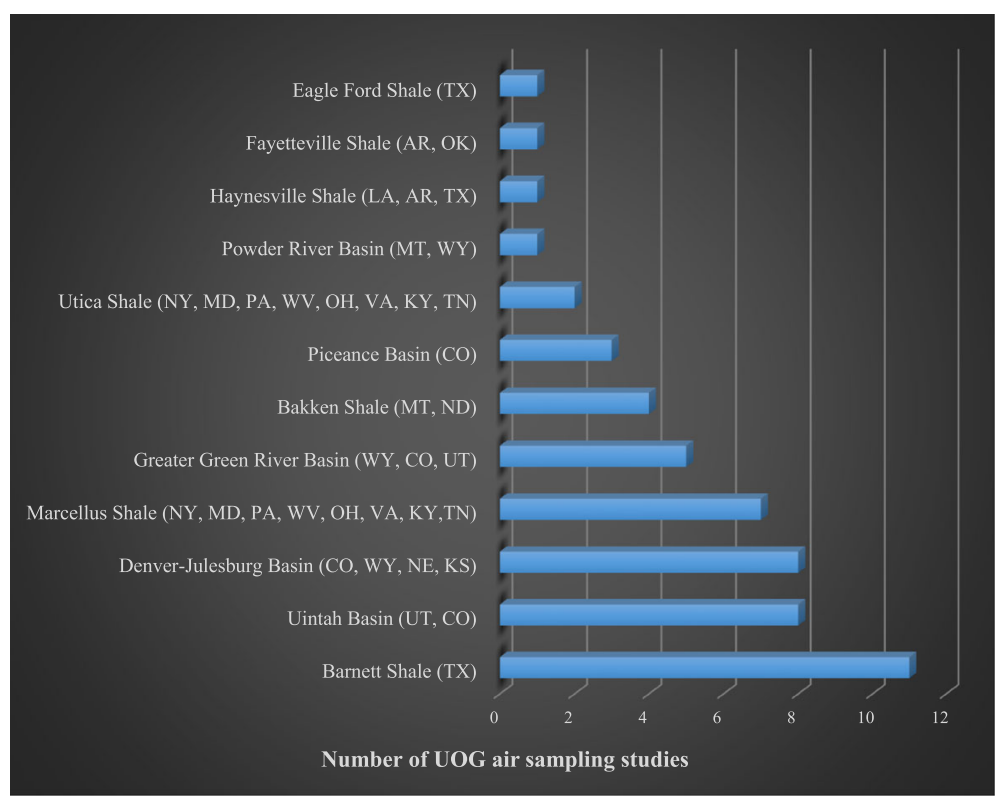

Fig. 1 Number of UOG air sampling studies by geologic formation. Air sampling has been performed in various UOG sites in the US. The most commonly sampled site in studies identified by our search was the Barnett Shale located in TX. The least frequently studied were Eagle Ford Shale, Fayetteville Shale, Haynesville Shale, and Powder River Basin. TX, Texas; AR, Arkansas; OK, Oklahoma; LA, Louisiana; MT, Montana; WY, Wyoming; NY, New York; MD, Maryland; PA, Pennsylvania; WV, West Virginia; OH, Ohio; VA, Virginia; KY, Kentucky; TN, Tennessee; CO, Colorado; ND, North Dakota; UT, Utah; KS, Kansas; NE, Nebraska; UOG, unconventional oil and gas

effects. Styrene seems to be of particular concern because in addition to the aforementioned evidence of endocrine activity it also appears to have evidence for glucocorticodogenic, thyroidogenic, and progestrogenic, activity and alterations of steroidgenesis.

In Fig. 2, the air sampling data (Table 1) was combined with the data that assessed possible endocrine activity (Tables 2 and 3). The chemicals identified as potentially endocrine active are listed along with the number of studies that detected them in air near sites of UOG activity. This list included 34 chemicals with $\mathrm{m}$-xylene and p-xylene counted separately, however they are combined (i.e., m,p-xylene) for the number of papers that detected them in the air to be consistent with how they are reported in that literature. In total, this list includes the 26 chemicals that were already on the TEDX List of Potential Endocrine Disruptors and the eight frequently detected UOG associated air pollutants that were found to have potential endocrine activity. Benzene, toluene, ethylbenzene, and xylenes (BTEX) were detected more frequently than PAHs and heavy metals such as mercury.

\section{Discussion}

Our study revealed more than 200 air chemicals in association with UOG activity at sites in the US. We identified 26 as being on the TEDX list, which identifies chemicals with endocrine activity, and an additional eight of the most frequently detected air pollutants were identified as having potential endocrine activity. Endocrine activities included estrogenicity, androgenicity and altered steroidogenesis. In addition, we included evidence from studies assessing endpoints related to developmental, neurophysiological and reproductive changes commonly mediated by hormones [55].

The BTEX compounds were among the top 10 most detected chemicals across the studies in our sample. This is likely due to the existence of less expensive detection methods and their recognition as HAPs according to the United States Environmental Protection Agency (US EPA) [56]. The toxicity of the BTEX chemicals has been extensively studied with respect to respiratory, cardiovascular, neurological, and carcinogenic impacts, yet according to recent studies it is becoming apparent that they may also have impacts on endocrine function [41, 57]. Styrene, a structurally related compound, was also frequently detected and appears to have the ability to interfere with several endocrine pathways potentially resulting in alterations in development and neurophysiology. This compound has been studied extensively for cancer related outcomes and is "reasonably anticipated to be a carcinogen," according to the National Toxicology Program [58]. Likewise, naphthalene is a possible carcinogen as well as a HAP [14] and appears to affect several different endocrine pathways. Few studies measured PAHs near UOG. One study that 


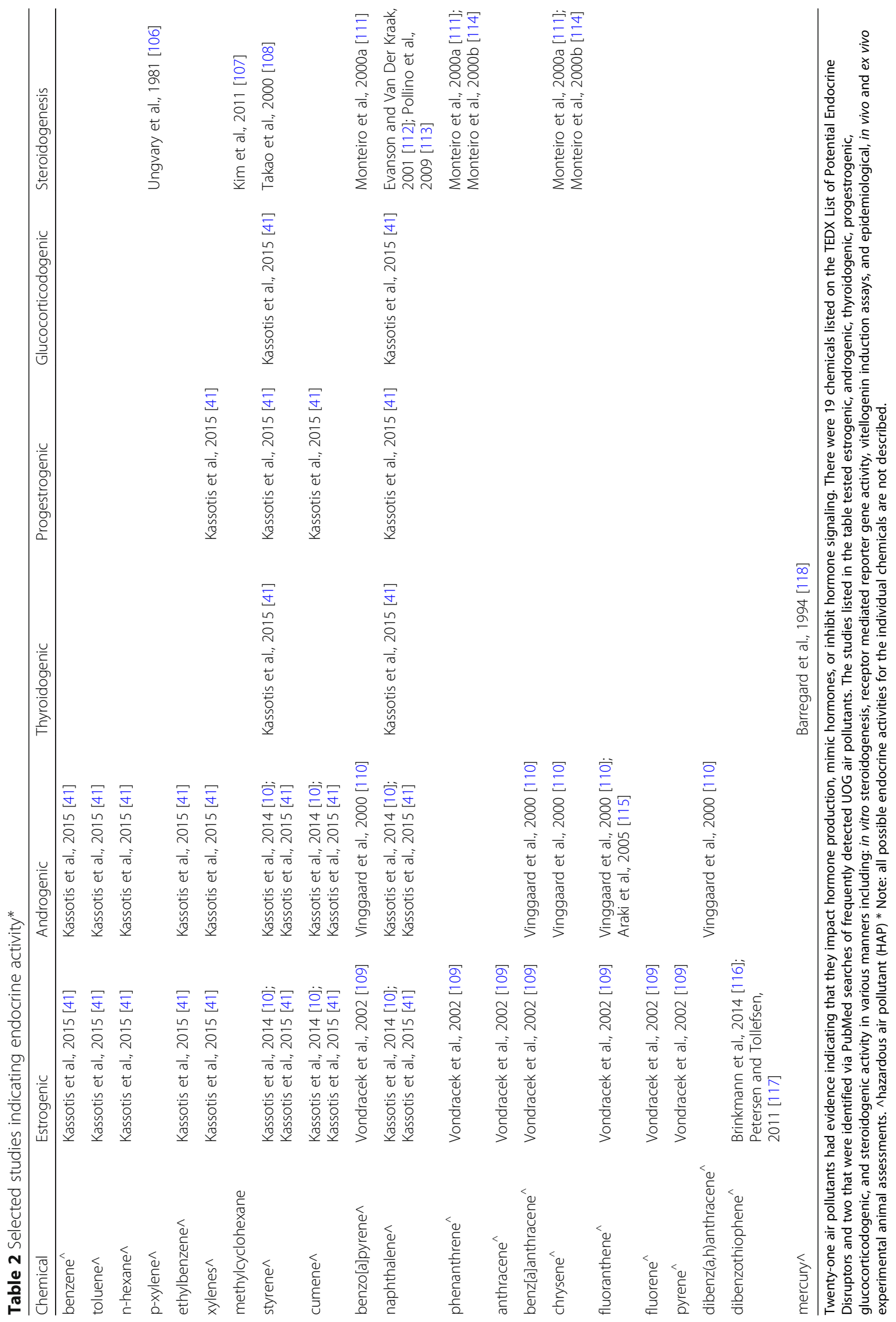




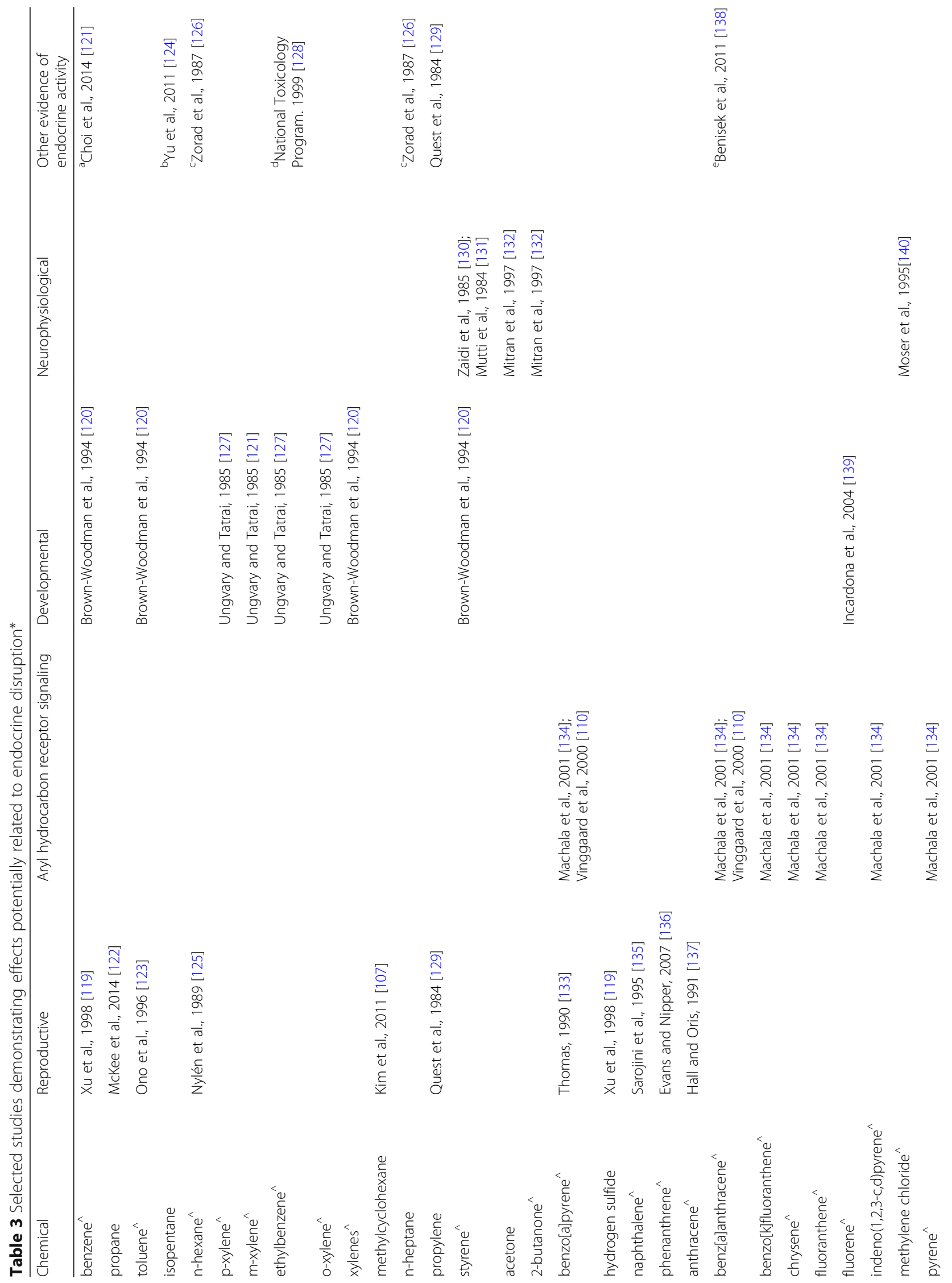




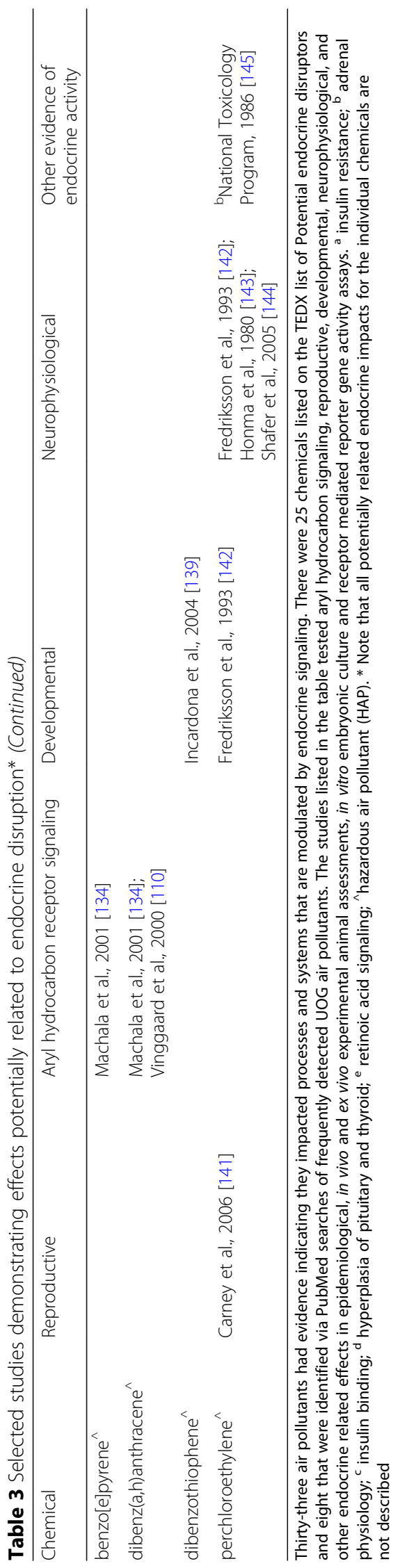




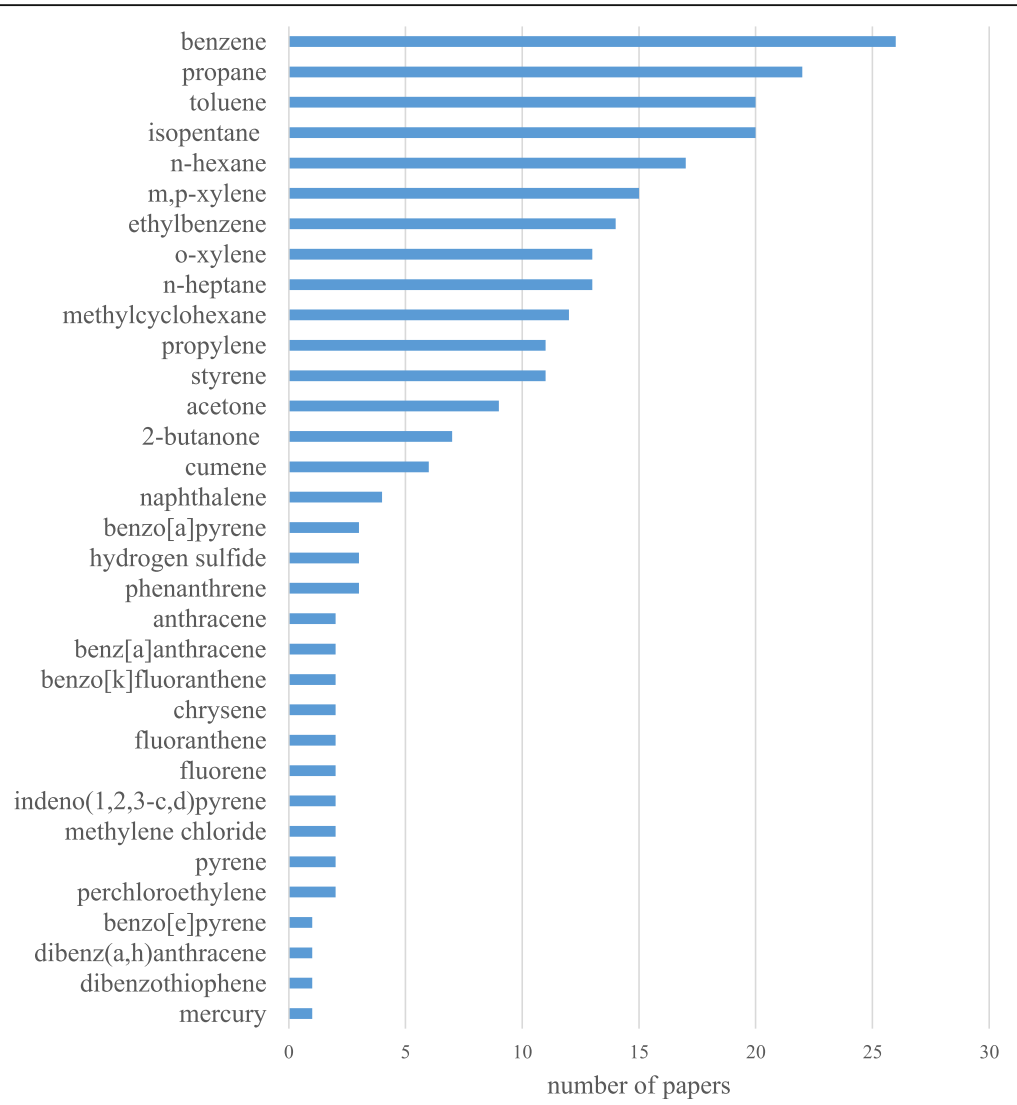

Fig. 2 Potentially endocrine active chemicals and the number of studies that identified them near UOG sites. The figure shows the 34 chemicals (with $\mathrm{m}$-xylene and p-xylene counted separately) that were identified as having evidence of endocrine active properties and the number of times they were detected in the air sampling papers included in this study. The graph show that the BTEX compounds (benzene, toluene, ethylbenzene, xylenes) were among the most frequently detected, and the polycyclic aromatic hydrocarbons (PAHs) were less frequently detected in air samples

measured a wide array of PAHs in the air near UOG found increased concentrations at sites closest to active wells. These levels did not exceed EPA's acceptable risk level for cancer, the only health effect addressed in the study [59]. In addition to carcinogenic properties, low level exposure to PAHs during prenatal development has been associated with delayed mental development, decreases in intelligence quotient (IQ), and childhood obesity [60-63]. Thus it is important to determine if they are pollutants commonly associated with UOG.

This study does not present a comprehensive review of research on the endocrine activity of compounds detected in the air near UOG. Rather, it serves to flag endocrine active compounds in order to inform future research on the potential health impacts of UOG. Further, some of the endocrine pathways have not been studied extensively and have not been replicated across models. In addition, some of the chemicals were not tested as inhalants in the studies we used to document endocrine disruption though this is the suspected primary route of exposure for the air pollutants evaluated. Our study only surveyed studies performed in the US, therefore it is possible that had we included studies from other countries the patterns of chemical detections may have differed. We also excluded foreign language studies, for lack of interpretive resources.

The review is limited by the fact that the primary studies routinely used standardized protocols (e.g., EPA Method TO-12, American Standard Test Method [ASTM] D-1357-95) that were likely informed by the US EPA's HAPs list, which would lead to a bias in terms of which chemicals are tested for and thus detected. In other words, there may be more chemicals present near UOG, particularly proprietary chemicals used in drilling and hydraulic fracturing, that have not been assessed near well pads or other facilities. Therefore, the present review is also limited in identifying other potentially endocrine active chemicals that have not yet been quantified or have been detected less frequently.

The published literature suggests a relationship between proximity to and/or density of UOG development and adverse health impacts in humans and wildlife, including outcomes that are a result of exposure to endocrine active compounds [10, 35-38, 40,64]. Our survey 
of the literature, while limited, supports these observations given that some of the air pollutants identified near sites of UOG activity are potentially endocrine active. Due to the types and hazards of the chemicals identified, there is a need to pursue additional long-term studies in humans and wildlife that investigate endocrine mediated health outcomes in order to understand whether or not exposure to endocrine active air pollutants results in disease. However, these studies are time-consuming, and a delay in action may be considered unethical since it is already known that 28 chemicals identified in our study are HAPs (i.e., "are known to cause cancer or other serious health impacts [56]") and several others have been studied thoroughly and identified as harmful to humans [65-68]. It was recently estimated that 17.6 million people in the US live within a mile of a well [69]. Thus, these populations may be exposed to air pollutants that have been linked to health impacts. It may be prudent to implement precautions similar to other industries that reduce exposure to air pollutants known to be health hazards.

For chemicals with sufficient bodies of literature but undefined hazard classifications, strategic execution of systematic reviews should follow as needed. These reviews would provide for a comprehensive analysis of the bodies of literature in order to determine confidence in the findings and/or potentially identify research gaps that might be addressed by more primary research. In addition, comprehensive environmental sampling of a broader array of chemicals (i.e., beyond HAPs) using novel laboratory techniques is necessary to establish if other air pollutants of concern are being emitted that are not included in standard testing protocols. Lastly, periodic updates to reviews, such as the present study, that assimilate new data are useful in characterizing the changing research landscape and can be used to redirect primary research efforts and policy actions as needed.

\section{Conclusions}

The results of this study provide a basis for directing future primary research about the endocrine disrupting properties of air pollutants near UOG sites including exposure research in wildlife and humans. In addition, thoughtfully designed systematic reviews of the health impacts of specific chemicals should be conducted. Environmental testing for emerging chemicals of concern is also recommended.

In closing, there is evidence that individual air pollutants associated with UOG activity are endocrine active. Endocrine disruptors can have actions at low exposure concentrations, and exposures can lead to aberrant trajectories resulting in suboptimal developmental, behavioral, reproductive, and metabolic conditions. Yet, the magnitude of exposures specific to UOG, and the possible long-term health impacts, are not well understood. Further, several of the chemicals we identified are already designated by the US EPA as suspected or known carcinogens, are known to cause adverse developmental or reproductive effects, and are known for other toxicities (e.g., hearing loss, and nerve damage). Given the potential for health impacts and the lack of safety recommendations for many of the chemicals we identified, there is an urgent need to address these releases near human and wildlife populations.

\section{Additional file}

Additional file 1: Table S1. Search terms used to identify air pollutants associated with UOG production. Table S2. PubMed search logic for chemicals with 10 or more detections from air studies that were not found on the TEDX List of Potential Endocrine Disruptors. Table S3. SWIFT search logic used to identify primary articles potentially describing ED activity. Table S4. List of chemicals reported as detected in air from 48 papers measuring air pollutants attributed to UOG activity. (DOCX 50 kb)

\section{Abbreviations \\ AR: Arkansas; ASTM: American Standard Test Method; BTEX: benzene, toluene, ethylbenzene, and xylenes; CO: Colorado; HAP: hazardous air pollutant; IQ: intelligence quotient; KS: Kansas; KY: Kentucky; LA: Louisiana; MD: Maryland; MT: Montana; ND: North Dakota; NE: Nebraska; NY: New York; $\mathrm{OH}$ : Ohio; OK: Oklahoma; PA: Pennsylvania; PAH: Polycyclic aromatic hydrocarbon; SWIFT: Sciome Workbench for Interactive computer-Facilitated Text-mining; TEDX: The Endocrine Disruption Exchange; TN: Tennessee; TX: Texas; UOG: unconventional oil and gas; US EPA: United States Environmental Protection Agency; US: United States; UT: Utah; VA: Virginia; VOC: volatile organic compounds; W: West Virginia; WY: Wyoming}

\section{Acknowledgements}

The authors would like to thank Christina Ribbens for her assistance with literature procurement.

\section{Funding}

Arkansas Community Foundation, Winslow Foundation, Cornell Douglas Foundation, Wallace Foundation, New-Land Foundation, and Tides Foundation.

\section{Availability of data and materials}

All data generated or analyzed during this study are included in this published article [and its supplementary information files].

\section{Authors' contributions}

Study conception and design: ALB, KS, and CFK; Acquisition of data: ALB, KS, and KEP; Analysis and interpretation of data: ALB, KS, and KEP; Drafting of manuscript: ALB, KS, KEP, and CFK; Critical revision: ALB, KS, KEP, and CFK. All authors read and approved the final manuscript.

Ethics approval and consent to participate Not applicable.

\section{Consent for publication}

Not applicable.

\section{Competing interests}

The authors declare that they have no competing interests.

\section{Publisher's Note}

Springer Nature remains neutral with regard to jurisdictional claims in published maps and institutional affiliations. 


\section{Author details}

${ }^{1}$ The Endocrine Disruption Exchange (TEDX), www.TEDX.org, Eckert, Colorado, USA. ${ }^{2}$ Department of Integrative Physiology, University of Colorado, Boulder, Colorado, USA. ${ }^{3}$ Biological Sciences, North Carolina State University, Raleigh, North Carolina, USA.

Received: 4 September 2017 Accepted: 20 February 2018 Published online: 21 March 2018

\section{References}

1. Colborn T, Schultz K, Herrick L, Kwiatkowski C. An exploratory study of air quality near natural gas operations. Hum Ecol Risk Assess. 2014;20(1):86-105. https://doi.org/10.1080/10807039.2012.749447.

2. Gilman JB, Lerner BM, Kuster WC, de Gouw JA. Source signature of volatile organic compounds from oil and natural gas operations in northeastern Colorado. Environ Sci Technol. 2013;47(3):1297-305. https://doi.org/10.1021/ es304119a.

3. Helmig D, Thompson CR, Evans J, Boylan P, Hueber J, Park JH. Highly elevated atmospheric levels of volatile organic compounds in the Uintah Basin, Utah. Environ Sci Technol. 2014;48(9):4707-15. https://doi.org/10.1021/ es405046r.

4. Macey GP, Breech R, Chernaik M, Cox C, Larson D, Thomas D, Carpenter DO. Air concentrations of volatile compounds near oil and gas production: a community-based exploratory study. Environ Health. 2014;13:82. https://doi. org/10.1186/1476-069x-13-82.

5. Rappenglück B, Ackermann L, Alvarez S, Golovko J, Buhr M, Field RA, Soltis J, Montague DC, Hauze B, Adamson S, Risch D, Wilkerson G, Bush D, Stoeckenius T, Keslar C. Strong wintertime ozone events in the Upper Green River Basin, Wyoming. Atmos Chem Phys. 2014;14(10):4909-34. https://doi. org/10.5194/acp-14-4909-2014.

6. Warneke C, Geiger F, Edwards PM, Dube W, Pétron G, Kofler J, Zahn A, Brown SS, Graus M, Gilman JB, Lerner BM, Peischl J, Ryerson TB, de Gouw JA, Roberts JM. Volatile organic compound emissions from the oil and natural gas industry in the Uintah Basin, Utah: Oil and gas well pad emissions compared to ambient air composition. Atmos Chem Phys. 2014; 14(20):10977-88. https://doi.org/10.5194/acp-14-10977-2014.

7. Zielinska B, Campbell D, Samburova V. Impact of emissions from natural gas production facilities on ambient air quality in the Barnett Shale area: a pilot study. J Air Waste Manag Assoc. 2014;64(12):1369-83. https://doi.org/10. 1080/10962247.2014.954735

8. Alawattegama SK, Kondratyuk T, Krynock R, Bricker M, Rutter JK, Bain DJ, Stolz JF. Well water contamination in a rural community in southwestern Pennsylvania near unconventional shale gas extraction. J Environ Sci Health A Tox Hazard Subst Environ Eng. 2015;50(5):516-28. https://doi.org/10.1080/ 10934529.2015.992684

9. Drollette BD, Hoelzer K, Warner NR, Darrah TH, Karatum O, O'Connor MP, Nelson RK, Fernandez LA, Reddy CM, Vengosh A, Jackson RB, Elsner M, Plata $\mathrm{DL}$. Elevated levels of diesel range organic compounds in groundwater near Marcellus gas operations are derived from surface activities. Proc Natl Acad Sci. 2015;112(43):13184-9. https://doi.org/10.1073/pnas.1511474112.

10. Kassotis CD, Tillitt DE, Davis JW, Hormann AM, Nagel SC. Estrogen and androgen receptor activities of hydraulic fracturing chemicals and surface and ground water in a drilling-dense region. Endocrinology. 2014;155(3): 897-907. https://doi.org/10.1210/en.2013-1697.

11. Adams MB. Land application of hydrofracturing fluids damages a deciduous forest stand in West Virginia. J Environ Qual. 2011;40(4):1340-4. https://doi. org/10.2134/jeq2010.0504.

12. Akob DM, Mumford AC, Orem WH, Engle MA, Klinges JG, Kent DB, Cozzarelli IM. Wastewater disposal from unconventional oil and gas development degrades stream quality at a West Virginia injection facility. Environ Sci Technol. 2016;50(11):5517-25. https://doi.org/10.1021/acs.est.6b00428.

13. Warner NR, Christie CA, Jackson RB, Vengosh A. Impacts of shale gas wastewater disposal on water quality in western Pennsylvania. Environ Sci Technol. 2013;47(20):11849-57. https://doi.org/10.1021/es402165b.

14. US House of Representatives Committee on Energy and Commerce Minority Staff, Chemicals Used in Hydraulic Fracturing. 2011.

15. Roscioli JR, Yacovitch TI, Floerchinger C, Mitchell AL, Tkacik DS, Subramanian R, Martinez DM, Vaughn TL, Williams L, Zimmerle D, Robinson AL, Herndon SC, Marchese AJ. Measurements of methane emissions from natural gas gathering facilities and processing plants: measurement methods. Atmos Meas Tech. 2015;8(5):2017-35. https://doi.org/10.5194/amt-8-2017-2015.
16. Rich A, Grover JP, Sattler ML. An exploratory study of air emissions associated with shale gas development and production in the Barnett Shale. J Air Waste Manag Assoc. 2014;64(1):61-72. https://doi.org/10.1080/ 10962247.2013 .832713$.

17. Allen DT, Pacsi AP, Sullivan DW, Zavala-Araiza D, Harrison M, Keen K, Fraser MP, Daniel Hill A, Sawyer RF, Seinfeld JH. Methane emissions from process equipment at natural gas production sites in the United States: Pneumatic controllers. Environ Sci Technol. 2015;49(1):633-40. https://doi.org/10.1021/ es5040156.

18. Allen DT, Sullivan DW, Zavala-Araiza D, Pacsi AP, Harrison M, Keen K, Fraser MP, Daniel Hill A, Lamb BK, Sawyer RF, Seinfeld JH. Methane emissions from process equipment at natural gas production sites in the United States: Liquid unloadings. Environ Sci Technol. 2015;49(1):641-8. https://doi.org/10. 1021/es504016r

19. Bloomdahl R, Abualfaraj N, Olson M, Gurian PL. Assessing worker exposure to inhaled volatile organic compounds from Marcellus Shale flowback pits. J Nat Gas Sci Eng. 2014;21:348-56. https://doi.org/10. 1016/j.jngse.2014.08.018

20. Field RA, Soltis J, McCarthy MC, Murphy S, Montaque DC. Influence of oil and gas field operations on spatial and temporal distributions of atmospheric non-methane hydrocarbons and their effect on ozone formation in winter. Atmos Chem Phys. 2015;15(6):3527-42. https://doi.org/ 10.5194/acp-15-3527-2015.

21. Hoelzer K, Sumner AJ, Karatum O, Nelson RK, Drollette BD, O'Connor MP, D’Ambro EL, Getzinger GJ, Ferguson PL, Reddy CM, Elsner M, Plata DL. Indications of transformation products from hydraulic fracturing additives in shale-gas wastewater. Environ Sci Technol. 2016;50(15):8036-48. https://doi. org/10.1021/acs.est.6b00430.

22. Bamberger M, Oswald RE. Long-term impacts of unconventional drilling operations on human and animal health. J Environ Sci Health A Tox Hazard Subst Environ Eng. 2015;50(5):447-59. https://doi.org/10.1080/10934529. 2015.992655.

23. Jemielita T, Gerton GL, Neidell M, Chillrud S, Yan B, Stute M, Howarth M, Saberi P, Fausti N, Penning TM, Roy J, Propert KJ, Panettieri RA Jr. Unconventional gas and oil drilling is associated with increased hospital utilization rates. PLoS One. 2015;10(7):e0131093. https://doi.org/10.1371/ journal.pone.0131093.

24. Slizovskiy IB, Conti LA, Trufan SJ, Reif JS, Lamers VT, Stowe MH, Dziura J, Rabinowitz PM. Reported health conditions in animals residing near natural gas wells in southwestern Pennsylvania. J Environ Sci Health A Tox Hazard Subst Environ Eng. 2015;50(5):473-81. https://doi.org/10.1080/10934529. 2015.992666.

25. Steinzor N, Subra W, Sumi L. Investigating links between shale gas development and health impacts through a community survey project in Pennsylvania. New Solut. 2013;23(1):55-83. https://doi.org/10.2190/NS.23.1.e.

26. Witter RZ, McKenzie L, Stinson KE, Scott K, Newman LS, Adgate J. The use of health impact assessment for a community undergoing natural gas development. Am J Public Health. 2013;103(6):1002-10. https://doi.org/10. 2105/AJPH.2012.301017.

27. Entrekin S, Evans-White M, Johnson B, Hagenbuch E. Rapid expansion of natural gas development poses a threat to surface waters. Fron Ecol Environ. 2011;9(9):503-11. https://doi.org/10.1890/110053.

28. Latta SC, Marshall LC, Frantz MW, Toms JD. Evidence from two shale regions that a riparian songbird accumulates metals associated with hydraulic fracturing. Ecosphere. 2015:6(9):144. https://doi.org/10.1890/ES14-00406.1.

29. Moran MD, Cox AB, Wells RL, Benichou CC, McClung MR. Habitat loss and modification due to gas development in the Fayetteville Shale. Environ Manage. 2015:55(6):1276-84. https://doi.org/10.1007/s00267-014-0440-6.

30. Rabinowitz PM, Slizovskiy IB, Lamers V, Trufan SJ, Holford TR, Dziura JD, Peduzzi PN, Kane MJ, Reif JS, Weiss TR, Stowe MH. Proximity to natural gas wells and reported health status: Results of a household survey in Washington County, Pennsylvania. Environ Health Perspect. 2015;123(1):216. https://doi.org/10.1289/ehp.1307732.

31. McKenzie LM, Witter RZ, Newman LS, Adgate JL. Human health risk assessment of air emissions from development of unconventional natural gas resources. Sci Total Environ. 2012:424:79-87. https://doi.org/10.1016/j. scitotenv.2012.02.018.

32. Rasmussen SG, Ogburn EL, McCormack M, et al. Association between unconventional natural gas development in the Marcellus Shale and asthma exacerbations. JAMA Internal Medicine. 2016;176(9):1334-43. https:// doi.org/10.1001/jamainternmed.2016.2436. 
33. Tustin AW, Hirsch A, Rasmussen S, Casey J, Bandeen-Roche K, Schwartz B. Associations between unconventional natural gas development and nasal and sinus, migraine headache, and fatigue symptoms in Pennsylvania. Envion Health Perspect. 2016;125:189-97. https://doi.org/10.1289/EHP281.

34. McKenzie LM, Allshouse WB, Byers TE, Bedrick EJ, Serdar B, Adgate JL. Childhood hematologic cancer and residential proximity to oil and gas development. PLoS ONE. 2017;12(2):e0170423. https://doi.org/10.1371/ journal.pone.0170423.

35. Casey JA, Savitz DA, Rasmussen SG, Ogburn EL, Pollak J, Mercer DG, Schwartz BS. Unconventional natural gas development and birth outcomes in Pennsylvania, USA. Epidemiology. 2015;27(2):163-72. https://doi.org/10. 1097/ede.0000000000000387

36. Whitworth KW, Marshall AK, Symanski E. Maternal residential proximity to unconventional gas development and perinatal outcomes among a diverse urban population in Texas. PLOS ONE. 2017;12(7):e0180966. https://doi.org/ 10.1371/journal.pone.0180966.

37. Stacy SL, Brink LL, Larkin JC, Sadovsky Y, Goldstein BD, Pitt BR, Talbott EO. Perinatal outcomes and unconventional natural gas operations in southwest Pennsylvania. PLoS ONE. 2015;10(6):e0126425. https://doi.org/10. 1371/journal.pone.0126425.

38. McKenzie LM, Guo R, Witter RZ, Savitz DA, Newman LS, Adgate JL. Birth outcomes and maternal residential proximity to natural gas development in rural Colorado. Environ Health Perspect. 2014;122(4):412-7. https://doi.org/ 10.1289/ehp.1306722.

39. Busby CMJ. There's a world going on underground —infant mortality and fracking in Pennsylvania. J Environ Prot. 2017;8(4):381-93. https://doi.org/10. 4236/jep.2017.84028.

40. Kassotis CD, Iwanowicz LR, Akob DM, Cozzarelli IM, Mumford AC, Orem WH, Nagel SC. Endocrine disrupting activities of surface water associated with a West Virginia oil and gas industry wastewater disposal site. Sci Total Environ. 2016;557-558:901-10. https://doi.org/10.1016/j.scitotenv.2016.03.11.

41. Kassotis CD, Klemp KC, Vu DC, Lin C-H, Meng C-X, Besch-Williford CL, Pinatti L, Zoeller RT, Drobnis EZ, Balise VD, Isiguzo CJ, Williams MA, Tillitt DE, Nagel SC. Endocrine-disrupting activity of hydraulic fracturing chemicals and adverse health outcomes after prenatal exposure in male mice. Endocrinology. 2015;156(12):4458-73. https://doi.org/10.1210/en.2015-1375.

42. Kassotis CD, Bromfield JJ, Klemp KC, Meng CX, Wolfe A, Zoeller RT, Balise VD, Isiguzo CJ, Tillitt DE, and Nagel SC, Adverse reproductive and developmental health outcomes following prenatal exposure to a hydraulic fracturing chemical mixture in female C57BI/6 mice. Endocrinology, 2016: p. en20161242; DOI: 10.1210/en.2016-1242.

43. He Y, Flynn SL, Folkerts EJ, Zhang Y, Ruan D, Alessi DS, Martin JW, Goss GG. Chemical and toxicological characterizations of hydraulic fracturing flowback and produced water. Water Res. 2017;114:78-87.

44. Folkerts EJ, Blewett TA, He Y, Goss GG. Cardio-respirometry disruption in zebrafish (Danio rerio) embryos exposed to hydraulic fracturing flowback and produced water. Environmental Pollution. 2017;231:1477-87. https://doi. org/10.1016/j.envpol.2017.09.011.

45. Folkerts EJ, Blewett TA, He Y, Goss GG. Alterations to Juvenile Zebrafish (Danio rerio) Swim Performance after Acute Embryonic Exposure to Sub-lethal Exposures of Hydraulic Fracturing Flowback and Produced Water. Aquatic Toxicology. 2017;193:50-9. https://doi.org/10.1016/j. aquatox.2017.10.003

46. He Y, Folkerts EJ, Zhang Y, Martin JW, Alessi DS, Goss GG. Effects on Biotransformation, Oxidative Stress, and Endocrine Disruption in Rainbow Trout (Oncorhynchus mykiss) Exposed to Hydraulic Fracturing Flowback and Produced Water. Environmental Science \& Technology. 2017;51(2):940-7. https://doi.org/10.1021/acs.est.6b04695.

47. Blewett TA, Delompre PL, He Y, Folkerts EJ, Flynn SL, Alessi DS, Goss GG. The sub-lethal and reproductive effects of acute and chronic exposure to flowback and produced water from hydraulic fracturing on the water flea Daphnia magna. Environ Sci Technol. 2017;51(5):3032-9. https://doi.org/10. 1021/acs.est.6b05179.

48. Evidence Partneers. DistillerSR. URL: http://distillercer.com/products/ distillersr-systematic-review-software/. 2016; Available from: http://distillercer com/products/distillersr-systematic-review-software/.

49. TEDX. The TEDX list of potential endocrine disurptors. 2016 [cited 2016 June 13]; Available from: https://endocrinedisruption.org/interactive-tools/tedxlist-of-potential-endocrine-disruptors/search-the-tedxlist.

50. Sciome. SWIFT-Review. 2016; Available from: http://www.sciome.com/ swift-review/.
51. Howard BE, Phillips J, Miller K, Tandon A, Mav D, Shah MR, Holmgren S, Pelch KE, Walker V, Rooney AA, Macleod M, Shah RR, Thayer K, SWIFTReview. A text-mining workbench for systematic review. Syst Rev. 2016;5:87.

52. Kiros BHB; Holmgren, S; Baker, N; Cleland, J; Walker, V; Antonic, A; Devito, M; Kwiatkowski, C; Bolden, A; Pelch, K; Zoeller, T; Thayer, K, Use of Text-mining and Machine Learning Approaches to Conduct a Rapid Literature Survey on Environmental Chemicals and the Thyroid. 2017. submitted.

53. Hurtt ME and Kennedy GL, Jr., A limited developmental toxicity study of pentane by inhalation in the rat. Food Chem Toxicol, 1999. 37(5): p. 565567; DOI: 10.1016/S0278-6915(99)00029-0.

54. Tabira Y, Nakai M, Asai D, Yakabe Y, Tahara Y, Shinmyozu T, Noguchi M, Takatsuki M, Shimohigashi Y. Structural requirements of para-alkylphenols to bind to estrogen receptor. Eur J Biochem. 1999;262(1):240-5. https://doi.org/ 10.1046/j.1432-1327.1999.00422.x

55. Gore AC, Chappell VA, Fenton SE, Flaws JA, Nadal A, Prins GS, Toppari J, Zoeller RT. EDC-2: The Endocrine Society's Second Scientific Statement on Endocrine-Disrupting Chemicals. Endocr Rev. 2015;36(6):E1-E150. https://doi. org/10.1210/er.2015-1010.

56. U.S. EPA Initial List of Hazardous Air Pollutants with Modifications. 2017 March 16, 2017 [cited 2017 May 13]; Available from: https://www.epa.gov/ haps/initial-list-hazardous-air-pollutants-modifications.

57. Bolden AL, Kwiatkowski CF, Colborn T. New look at BTEX: Are ambient levels a problem? Environ Sci Technol. 2015;49(9):5261-76. https://doi.org/10.1021/ es505316f.

58. NTP, NTP Report on Carcinogens: Styene CAS No. 100-42-5. 2016, Department of Health and Human Services.

59. Paulik LB, Donald CE, Smith BW, Tidwell LG, Hobbie KA, Kincl L, Haynes EN, Anderson KA. Emissions of polycyclic aromatic hydrocarbons from natural gas extraction into air. Environ Sci Technol. 2016;50(14):7921-9. https://doi. org/10.1021/acs.est.6b02762.

60. Rundle A, Hoepner L, Hassoun A, Oberfield S, Freyer G, Holmes D, Reyes M, Quinn J, Camann D, Perera F, Whyatt R. Association of childhood obesity with maternal exposure to ambient air polycyclic aromatic hydrocarbons during pregnancy. Am J Epidemiol. 2012;175(11):1163-72. https://doi.org/10. 1093/aje/kwr455.

61. Perera FP, Rauh V, Whyatt RM, Tsai WY, Tang DL, Diaz D, Hoepner L, Barr D, Tu YH, Camann D, Kinney P. Effect of prenatal exposure to airborne polycyclic aromatic hydrocarbons on neurodevelopment in the first 3 years of life among inner-city children. Environmental Health Perspectives. 2006; 114(8):1287-92. https://doi.org/10.1289/ehp.9084.

62. Perera FP, Li Z, Whyatt R, Hoepner L, Wang S, Camann D, Rauh V. Prenatal airborne polycyclic aromatic hydrocarbon exposure and child IQ at age 5 years. Pediatrics. 2009;124(2):e195-202. https://doi.org/10.1542/peds.2008-3506.

63. Perera F, Herbstman J. Prenatal environmental exposures, epigenetics, and disease. Reprod Toxicol. 2011;31(3):363-73. https://doi.org/10.1016/j. reprotox.2010.12.055.

64. Cozzarelli IM, Skalak KJ, Kent DB, Engle MA, Benthem A, Mumford AC, Haase K, Farag A, Harper D, Nagel SC, Iwanowicz LR, Orem WH, Akob DM, Jaeschke JB, Galloway J, Kohler M, Stoliker DL, Jolly GD. Environmental signatures and effects of an oil and gas wastewater spill in the Williston Basin, North Dakota. Science of The Total Environment. 2017:579:1781-93. https://doi.org/10.1016/j.scitotenv.2016.11.157.

65. Annavarapu RN and Kathi S, Cognitive disorders in children associated with urban vehicular emissions. Environ Pollut, 2016. 208(Pt A): p. 74-78; DOl: 10. 1016/j.envpol.2015.09.036.

66. Caruso JA, Zhang K, Schroeck NJ, McCoy B, McElmurry SP. Petroleum coke in the urban environment: a review of potential health effects. Int J Environ Res Public Health. 2015;12(6):6218-31. https://doi.org/10.3390/ ijerph120606218.

67. Niaz K, Bahadar H, Maqbool F, Abdollahi M. A review of environmental and occupational exposure to xylene and its health concerns. EXCLI J. 2015;14: 1167-86. https://doi.org/10.17179/excli2015-623.

68. Perera FP, Rauh V, Whyatt RM, Tang D, Tsai WY, Bernert JT, Tu YH, Andrews H, Barr DB, Camann DE, Diaz D, Dietrich J, Reyes A, Kinney PL. A summary of recent findings on birth outcomes and developmental effects of prenatal ETS, PAH, and pesticide exposures. Neurotoxicology. 2005;26(4):573-87. https://doi.org/10.1016/j.neuro.2004.07.007.

69. Czolowski E, Santoro R, Srebotnjak T, and Shonkoff S, Toward consistent methodology to quantify populations in proximity to oil and gas development: a national spatial analysis and review. Environ Health Perspect, 2017. 125(8): p. DOI: 10.1289/EHP1535. 
70. Brantley HL, Thoma ED, Eisele AP. Assessment of volatile organic compound and hazardous air pollutant emissions from oil and natural gas well pads using mobile remote and on-site direct measurements. J Air Waste Manag Assoc. 2015;65(9):1072-82. https://doi.org/10.1080/10962247.2015.1056888.

71. Eapi GR, Sabnis MS, Sattler ML. Mobile measurement of methane and hydrogen sulfide at natural gas production site fence lines in the Texas Barnett Shale. J Air Waste Manag Assoc. 2014;64(8):927-44. https://doi.org/ 10.1080/10962247.2014.907098.

72. Eisele AP, Mukerjee S, Smith LA, Thoma ED, Whitaker DA, Oliver KD, Wu T, Colon M, Alston L, Cousett TA, Miller MC, Smith DM, Stallings C. Volatile organic compounds at two oil and natural gas production well pads in Colorado and Texas using passive samplers. J Air Waste Manag Assoc. 2016; 66(4):412-9. https://doi.org/10.1080/10962247.2016.1141808.

73. Esswein EJ, Snawder J, King B, Breitenstein M, Alexander-Scott M, Kiefer M. Evaluation of some potential chemical exposure risks during flowback operations in unconventional oil and gas extraction: Preliminary results. J Occup Environ Hyg. 2014;11(10):D174-84. https://doi.org/10.1080/15459624. 2014.933960.

74. Field R, Soltis J, Pérez-Ballesta P, Grandesso E, and Montague D, Distributions of air pollutants associated with oil and natural gas development measured in the Upper Green River Basin of Wyoming. Elem Sci Anth, 2015. 3(1): p. 74; DOI: 10.12952/journal.elementa.000074.

75. Goetz JD, Floerchinger C, Fortner EC, Wormhoudt J, Massoli P, Knighton WB, Herndon SC, Kolb CE, Knipping E, Shaw SL, DeCarlo PF. Atmospheric emission characterization of Marcellus Shale natural gas development sites. Environ Sci Technol. 2015;49(11):7012-20. https://doi.org/10.1021/acs.est.5b00452.

76. Katzenstein AS, Doezema LA, Simpson IJ, Blake DR, Rowland FS. Extensive regional atmospheric hydrocarbon pollution in the southwestern United States. Proc Natl Acad Sci U S A. 2003;100(21):11975-9. https://doi.org/10. 1073/pnas.1635258100.

77. Koss AR, de Gouw J, Warneke C, Gilman JB, Lerner BM, Graus M, Yuan B, Edwards P, Brown SS, Wild R, Roberts JM, Bates TS, Quinn PK. Photochemical aging of volatile organic compounds associated with oil and natural gas extraction in the Uintah Basin, UT, during a wintertime ozone formation event. Atmos Chem Phys. 2015;15(10):5727-41. https://doi.org/10. 5194/acp-15-5727-2015.

78. Lan X, Talbot R, Laine P, Torres A, Lefer B, Flynn J. Atmospheric mercury in the Barnett Shale area, Texas: Implications for emissions from oil and gas processing. Environ Sci Technol. 2015;49(17):10692-700. https://doi.org/10. 1021/acs.est.5b02287.

79. Lee L, Wooldridge PJ, deGouw J, Brown SS, Bates TS, Quinn PK, Cohen RC. Particulate organic nitrates observed in an oil and natural gas production region during wintertime. Atmos Chem Phys. 2015;15(16):9313-25. https:// doi.org/10.5194/acp-15-9313-2015.

80. Li C, Hsu NC, Sayer AM, Krotkov NA, Fu JS, Lamsal LN, Lee J, and Tsay SC, Satellite observation of pollutant emissions from gas flaring activities near the Arctic. Atmos Environ, 2016. 133: p. 1-11; DOl: 10.1016/j.atmosenv.2016. 03.019.

81. Li R, Warneke C, Graus M, Field R, Geiger F, Veres PR, Soltis J, Li SM, Murphy SM, Sweeney C, Petron G, Roberts JM, de Gouw J. Measurements of hydrogen sulfide (H2S) using PTR-MS: Calibration, humidity dependence, inter-comparison and results from field studies in an oil and gas production region. Atmos Meas Tech. 2014;7(10):3597-610. https://doi.org/10.5194/amt7-3597-2014.

82. Lyman S, Tran T. Inversion structure and winter ozone distribution in the Uintah Basin, Utah, USA. Atmos Environ. 2015;123:156-65. https://doi.org/10. 1016/j.atmosenv.2015.10.067.

83. Olaguer EP, Erickson M, Wijesinghe A, Neish B, Williams J, Colvin J. Updated methods for assessing the impacts of nearby gas drilling and production on neighborhood air quality and human health. J Air Waste Manag Assoc. 2016;66(2):173-83. https://doi.org/10.1080/10962247.2015.1083914.

84. Oltmans S, Schnell R, Johnson B, Petron G, Mefford T, and Neely R, III, Anatomy of wintertime ozone associated with oil and natural gas extraction activity in Wyoming and Utah. Elem Sci Anth, 2014. 2: p. 24; DOI: 10.12952/ journal.elementa.000024.

85. Omara M, Sullivan MR, Li X, Subramanian R, Robinson AL, Presto AA. Methane emissions from conventional and unconventional natural gas production sites in the Marcellus Shale basin. Environ Sci Technol. 2016; 50(4):2099-107. https://doi.org/10.1021/acs.est.5b05503.

86. Peischl J, Karion A, Sweeney C, Kort EA, Smith ML, Brandt AR, Yeskoo T, Aikin KC, Conley SA, Gvakharia A, Trainer M, Wolter S, Ryerson TB.
Quantifying atmospheric methane emissions from oil and natural gas production in the Bakken Shale region of North Dakota. J Geophys Res Atmos. 2016;121(10):6101-11. https://doi.org/10.1002/2015jd024631.

87. Pekney NJ, Veloski G, Reeder M, Tamilia J, Rupp E, Wetzel A. Measurement of atmospheric pollutants associated with oil and natural gas exploration and production activity in Pennsylvania's Allegheny National Forest. J Air Waste Manag Assoc. 2014;64(9):1062-72. https://doi.org/10.1080/10962247. 2014.897270 .

88. Petron G, Frost G, Miller BR, Hirsch Al, Montzka SA, Karion A, Trainer M, Sweeney C, Andrews AE, Miller L, Kofler J, Bar-llan A, Dlugokencky EJ, Patrick L, Moore CT, Ryerson TB, Siso C, Kolodzey W, Lang PM, Conway T, Novelli P, Masarie K, Hall B, Guenther D, Kitzis D, Miller J, Welsh D, Wolfe D, Neff W, Tans P. Hydrocarbon emissions characterization in the Colorado Front Range: A pilot study. J Geophys Res Atmos. 2012;117(D4):2156-202. https:// doi.org/10.1029/2011jd016360.

89. Petron G, Karion A, Sweeney C, Miller BR, Montzka SA, Frost GJ, Trainer M, Tans P, Andrews A, Kofler J, Helmig D, Guenther D, Dlugokencky E, Lang P, Newberger T, Wolter S, Hall B, Novelli P, Brewer A, Conley S, Hardesty M, Banta R, White A, Noone D, Wolfe D, Schnell R. A new look at methane and nonmethane hydrocarbon emissions from oil and natural gas operations in the Colorado Denver-Julesburg Basin. J Geophys Res Atmos. 2014;119(11): 6836-52. https://doi.org/10.1002/2013jd021272.

90. Prenni AJ, Day DE, Evanoski-Cole AR, Sive BC, Hecobian A, Zhou Y, Gebhart KA, Hand JL, Sullivan AP, Li Y, Schurman MI, Desyaterik Y, Malm WC, Collett $J \mathrm{~L}, \mathrm{Jr}$., and Schichtel BA, Oil and gas impacts on air quality in federal lands in the Bakken region: an overview of the Bakken Air Quality Study and first results. Atmos Chem Phys, 2016. 16(3): p. 1401-1416; DOI: https://doi.org/10. 5194/acp-16-1401-2016.

91. Rich AL, Orimoloye HT. Elevated atmospheric levels of benzene and benzene-related compounds from unconventional shale extraction and processing: Human health concern for residential communities. Environ Health Insights. 2016;10:75-82. https://doi.org/10.4137/ehi.s33314.

92. Rutter AP, Griffin RJ, Cevik BK, Shakya KM, Gong L, Kim S, Flynn JH, Lefer BL. Sources of air pollution in a region of oil and gas exploration downwind of a large city. Atmos Environ. 2015;120:89-99. https://doi.org/10.1016/j. atmosenv.2015.08.073.

93. Schnell RC, Oltmans SJ, Neely RR, Endres MS, Molenar JV, White AB. Rapid photochemical production of ozone at high concentrations in a rural site during winter. Nature Geosci. 2009;2(2):120-2. https://doi.org/10.1038/ ngeo415.

94. Schwarz JP, Holloway JS, Katich JM, McKeen S, Kort EA, Smith ML, Ryerson TB, Sweeney C, Peischl J. Black carbon emissions from the Bakken oil and gas development region. Environ Sci Technol Lett. 2015;2(10):281-5. https:// doi.org/10.1021/acs.estlett.5b00225.

95. Smith ML, Kort EA, Karion A, Sweeney C, Herndon SC, Yacovitch TI. Airborne ethane observations in the Barnett Shale: Quantification of ethane flux and attribution of methane emissions. Environ Sci Technol. 2015;49(13):8158-66. https://doi.org/10.1021/acs.est.5b00219.

96. Swarthout RF, Russo RS, Zhou Y, Hart AH, Sive BC. Volatile organic compound distributions during the NACHTT campaign at the Boulder Atmospheric Observatory: Influence of urban and natural gas sources. J Geophys Res Atmos. 2013;118(18):10614-37. https://doi.org/10.1002/jgrd. 50722.

97. Swarthout RF, Russo RS, Zhou Y, Miller BM, Mitchell B, Horsman E, Lipsky E, McCabe DC, Baum E, Sive BC. Impact of Marcellus Shale natural gas development in southwest Pennsylvania on volatile organic compound emissions and regional air quality. Environ Sci Technol. 2015;49(5):3175-84. https://doi.org/10.1021/es504315f.

98. Thompson CR, Hueber J, and Helmig D, Influence of oil and gas emissions on ambient atmospheric non-methane hydrocarbons in residential areas of northeastern Colorado. Elem Sci Anth, 2014. 3: p. 35; DOI: 10.12952/journal. elementa.000035

99. Townsend-Small A, Marrero JE, Lyon DR, Simpson IJ, Meinardi S, Blake DR. Integrating source apportionment tracers into a bottom-up inventory of methane emissions in the Barnett Shale hydraulic fracturing region. Environ Sci Technol. 2015;49(13):8175-82. https://doi. org/10.1021/acs.est.5b00057.

100. Vinciguerra T, Yao S, Dadzie J, Chittams A, Deskins T, Ehrman S, Dickerson RR. Regional air quality impacts of hydraulic fracturing and shale natural gas activity: Evidence from ambient VOC observations. Atmos Environ. 2015;110: 144-50. https://doi.org/10.1016/j.atmosenv.2015.03.056. 
101. Warneke C, Veres P, Murphy SM, Soltis J, Field RA, Graus MG, Koss A, Li SM, Li R, Yuan B, Roberts JM, de Gouw JA. PTR-QMS versus PTR-TOF comparison in a region with oil and natural gas extraction industry in the Uintah Basin in 2013. Atmos Meas Tech. 2015;8(1):411-20. https://doi.org/10.5194/amt-8-411-2015.

102. Weyant $C L$, Shepson PB, Subramanian R, Cambaliza MO, Heimburger A, McCabe D, Baum E, Stirm BH, Bond TC. Black carbon emissions from associated natural gas flaring. Environ Sci Technol. 2016;50(4):2075-81. https://doi.org/10.1021/acs.est.5b04712.

103. Yacovitch TI, Herndon SC, Petron G, Kofler J, Lyon D, Zahniser MS, Kolb CE. Mobile laboratory observations of methane emissions in the Barnett Shale region. Environ Sci Technol. 2015;49(13):7889-95. https://doi.org/10.1021/ es506352j.

104. Yuan B, Kaser L, Karl T, Graus M, Peischl J, Campos TL, Shertz S, Apel EC, Hornbrook RS, Hills A, Gilman JB, Lerner BM, Warneke C, Flocke FM, Ryerson $T B$, Guenther AB, de Gouw JA. Airborne flux measurements of methane and volatile organic compounds over the Haynesville and Marcellus Shale gas production regions. J Geophys Res Atmos. 2015;120(12):6271-89. https://doi. org/10.1002/2015jd023242.

105. Zavala-Araiza D, Sullivan DW, Allen DT. Atmospheric hydrocarbon emissions and concentrations in the Barnett Shale natural gas production region. Environ Sci Technol. 2014;48(9):5314-21. https://doi.org/10.1021/es405770h.

106. Ungvary G, Varga B, Horvath E, Tatrai E, Folly G. Study on the role of maternal sex steroid production and metabolism in the embryotoxicity of para-xylene. Toxicology. 1981;19(3):263-8. https://doi.org/10.1016/0300483X(81)90136-0.

107. Kim HY, Kang MG, Kim TG, Kang CW. Toxicity of methylcyclohexane and its effect on the reproductive system in SD rats. Saf Health Work. 2011;2(3): 290-300. https://doi.org/10.5491/shaw.2011.2.3.290.

108. Takao T, Nanamiya W, Nazerloo HP, Asaba K, Hashimoto K. Possible reproductive toxicity of styrene in peripubertal male mice. Endocrine Journal. 2000;47(3):343-7. https://doi.org/10.1507/endocrj.47.343.

109. Vondracek J, Kozubík A, Machala M. Modulation of estrogen receptordependent reporter construct activation and $\mathrm{G}_{0} / \mathrm{G}_{1}$-S-phase transition by polycyclic aromatic hydrocarbons in human breast carcinoma MCF-7 cells. Toxicol Sci. 2002;70(2):193-201. https://doi.org/10.1093/toxsci/70.2.193.

110. Vinggaard AM, Hnida C, Larsen JC. Environmental polycyclic aromatic hydrocarbons affect androgen receptor activation in vitro. Toxicology. 2000; 145(2-3):173-83. https://doi.org/10.1016/S0300-483X(00)00143-8.

111. Monteiro PRR, Reis-Henriques MA, Coimbra J. Polycyclic aromatic hydrocarbons inhibit in vitro ovarian steroidogenesis in the flounder (Platichthys flesus L.). Aquat Toxicol. 2000;48(4):549-59. https://doi.org/10. 1016/S0166-445X(99)00055-7.

112. Evanson M, Van Der Kraak GJ. Stimulatory effects of selected PAHs on testosterone production in goldfish and rainbow trout and possible mechanisms of action. Comp Biochem Physiol C Toxicol Pharmacol. 2001; 130(2):249-58. https://doi.org/10.1016/S1532-0456(01)00246-0.

113. Pollino CA, Georgiades E, Holdway DA. Physiological changes in reproductively active rainbowfish (Melanotaenia fluviatilis) following exposure to naphthalene. Ecotoxicol Environ Saf. 2009;72(4):1265-70. https://doi.org/10.1016/j.ecoenv.2009.01.012.

114. Monteiro PRR, Reis-Henriques MA, Coimbra J. Plasma steroid levels in female flounder (Platichthys flesus) after chronic dietary exposure to single polycyclic aromatic hydrocarbons. Mar Environ Res. 2000;49(5):453-67. https://doi.org/10.1016/S0141-1136(99)00085-9.

115. Araki N, Ohno K, Takeyoshi M, lida M. Evaluation of a rapid in vitro androgen receptor transcriptional activation assay using AR-EcoScreen cells. Toxicol In Vitro. 2005;19(3):335-52. https://doi.org/10.1016/j.tiv.2004.10.008.

116. Brinkmann M, Maletz S, Krauss M, Bluhm K, Schiwy S, Kuckelkorn J, Tiehm A, Brack W, Hollert H. Heterocyclic aromatic hydrocarbons show estrogenic activity upon metabolization in a recombinant transactivation assay. Environ Sci Technol. 2014;48(10):5892-901. https://doi.org/10.1021/es405731j.

117. Petersen K, Tollefsen KE. Assessing combined toxicity of estrogen receptor agonists in a primary culture of rainbow trout (Oncorhynchus mykiss) hepatocytes. Aquat Toxicol. 2011;101(1):186-95. https://doi.org/10.1016/j. aquatox.2010.09.018

118. Barregård L, Lindstedt G, Schutz A, Sällsten G. Endocrine function in mercury exposed chloralkali workers. Occup Environ Med. 1994;51(8):536-40.

119. Xu XP, Cho SI, Sammel M, You LY, Cui SC, Huang YM, Ma GH, Padungtod C, Pothier L, Niu TH, Christiani D, Smith T, Ryan L, Wang LH. Association of petrochemical exposure with spontaneous abortion. Occup Environ Med. 1998:55(1):31-6.
120. Brown-Woodman PD, Webster WS, Picker K, Huq F. In vitro assessment of individual and interactive effects of aromatic hydrocarbons on embryonic development of the rat. Reprod Toxicol. 1994;8(2):121-35. https://doi.org/10. 1016/0890-6238(94)90019-1.

121. Choi YH, Kim JH, Lee BE, Hong YC. Urinary benzene metabolite and insulin resistance in elderly adults. Sci Total Environ. 2014;482-483:260-8. https:// doi.org/10.1016/j.scitotenv.2014.02.121.

122. McKee RH, Herron D, Saperstein M, Podhasky P, Hoffman GM, Roberts L. The toxicological properties of petroleum gases. Int J Toxicol. 2014;33(1 Suppl): 28S-51S. https://doi.org/10.1177/1091581813504225.

123. Ono A, Sekita K, Ogawa Y, Hirose A, Suzuki S, Saito M, Naito K, Kaneko T, Furuya T, Kawashima K, Yasuhara K, Matsumoto K, Tanaka S, Inoue T, Kurokawa Y. Reproductive and developmental toxicity studies of toluene. II. Effects of inhalation exposure on fertility in rats. J Environ Pathol Toxicol Oncol. 1996;15(1):9-20. https://doi.org/10.2131/jts.20.109.

124. Yu WJ, Chung MK, Chung YH, Kim HC, Kim SH, Lee IC, Kim JC. Onegeneration reproductive toxicity study of 2-methylbutane in SpragueDawley rats. Regul Toxicol Pharmacol. 2011;60(1):136-43. https://doi.org/10. 1016/j.yrtph.2011.03.003.

125. Nylén P, Ebendal T, Eriksdotter-Nilsson M, Hansson T, Henschen A, Johnson AC, Kronevi T, Kvist U, Sjöstrand NO, Höglund G, Olson L. Testicular atrophy and loss of nerve growth factor-immunoreactive germ cell line in rats exposed to $n$-hexane and a protective effect of simultaneous exposure to toluene or xylene. Arch Toxicol. 1989;63(4):296-307. https://doi.org/10.1007/ BF00278643.

126. Zorad S, Klimes I, Svabova E, Mitkova A, Macho L. n-Heptane and n-hexane enhance in a dose-dependent manner insulin binding to erythrocytes and its degradation. Gen Physiol Biophys. 1987;6(2):197-201.

127. Ungvary G, Tatrai E. On the embryotoxic effects of benzene and its alkyl derivatives in mice, rats and rabbits. Arch Toxicol Suppl. 1985;8:425-30.

128. NTP. NTP Toxicology and Carcinogenesis Studies of Ethylbenzene (CAS No. 100-41-4) in F344/N Rats and B6C3F1 Mice (Inhalation Studies). Natl Toxicol Program Tech Rep Ser. 1999;466:1-231.

129. Quest JA, Tomaszewski JE, Haseman JK, Boorman GA, Douglas JF, and Clarke WJ, Two-year inhalation toxicity study of propylene in F344/N rats and B6C3F1 mice. Toxicol Appl Pharmacol, 1984. 76(2): p. 288-295; DOl; 10. 1016/0041-008X(84)90010-3.

130. Zaidi NF, Agrawal AK, Srivastava SP, Seth PK. Effect of gestational and neonatal styrene exposure on dopamine receptors. Neurobehav Toxicol Teratol. 1985;7(1):23-8.

131. Mutti A, Vescovi PP, Falzoi M, Arfini G, Valenti G, Franchini I. Neuroendocrine effects of styrene on occupationally exposed workers. Scand J Work Environ Health. 1984;10(4):225-8. https://doi.org/10.5271/sjweh.2340.

132. Mitran E, Callender T, Orha B, Dragnea P, Botezatu G. Neurotoxicity associated with occupational exposure to acetone, methyl ethyl ketone, and cyclohexanone. Environ Res. 1997;73(1-2):181-8. https://doi.org/10.1006/ enrs.1997.3703.

133. Thomas $P$. Teleost model for studying the effects of chemicals on female reproductive endocrine function. J Exp Zool Supp. 1990;4:126-8. https://doi. org/10.1002/jez.1402560421.

134. Machala M, Vondracek J, Blaha L, Ciganek M, Neca JV. Aryl hydrocarbon receptor-mediated activity of mutagenic polycyclic aromatic hydrocarbons determined using in vitro reporter gene assay. Mutat Res. 2001;497(1-2):4962. https://doi.org/10.1016/S1383-5718(01)00240-6.

135. Sarojini R, Nagabhushanam R, Fingerman M. Naphthalene-induced atresia in the ovary of the crayfish, Procambarus clarkii. Ecotoxicol Environ Saf. 1995; 31(1):76-83. https://doi.org/10.1006/eesa.1995.1046.

136. Evans AD, Nipper M. Toxicity of phenanthrene and lindane mixtures to marine invertebrates. Environ Toxicol. 2007;22(5):495-501. https://doi.org/10 1002/tox.20279

137. Hall AT, Oris JT. Anthracene reduces reproductive potential and is maternally transferred during long-term exposure in fathead minnows. Aquat Toxicol. 1991;19(3):249-64. https://doi.org/10.1016/0166445X(91)90022.

138. Benisek M, Kubincova P, Blaha L, Hilscherova K. The effects of PAHs and NPAHs on retinoid signaling and Oct-4 expression in vitro. Toxicol Lett. 2011; 200(3):169-75. https://doi.org/10.1016/j.toxlet.2010.11.011.

139. Incardona JP, Collier TK, Scholz NL. Defects in cardiac function precede morphological abnormalities in fish embryos exposed to polycyclic aromatic hydrocarbons. Toxicol Appl Pharmacol. 2004;196(2):191-205. https://doi.org/ 10.1016/j.taap.2003.11.026. 
140. Moser VC, Cheek BM, MacPhail RC. A multidisciplinary approach to toxicological screening. III. Neurobehavioral toxicity. J Toxicol Environ Health. 1995;45(2):173-210. https://doi.org/10.1080/15287399509531988.

141. Carney EW, Thorsrud BA, Dugard PH, Zablotny CL. Developmental toxicity studies in $\mathrm{Crl}: \mathrm{CD}(\mathrm{SD})$ rats following inhalation exposure to trichloroethylene and perchloroethylene. Birth Defects Res B Dev Reprod Toxicol. 2006;77(5): 405-12. https://doi.org/10.1002/bdrb.20091.

142. Fredriksson A, Danielsson BR, Eriksson P. Altered behaviour in adult mice orally exposed to tri- and tetrachloroethylene as neonates. Toxicol Lett. 1993;66(1):13-9. https://doi.org/10.1016/0378-4274(93)90074-8.

143. Honma T, Sudo A, Miyagawa M, Sato M, Hasegawa H. Effects of exposure to trichloroethylene and tetrachloroethylene on the contents of acetylcholine, dopamine, norepinephrine and serotonin in rat brain. Ind Health. 1980;18(4): 171-8. https://doi.org/10.2486/indhealth.18.171.

144. Shafer TJ, Bushnell PJ, Benignus VA, Woodward JJ. Perturbation of voltagesensitive Ca2+ channel function by volatile organic solvents. J Pharmacol Exp Ther. 2005;315(3):1109-18. https://doi.org/10.1124/jpet.105.090027.

145. NTP. NTP Toxicology and Carcinogenesis Studies of Tetrachloroethylene (Perchloroethylene) (CAS No. 127-18-4) in F344/N Rats and B6C3F1 Mice (Inhalation Studies). Natl Toxicol Program Tech Rep Ser. 1986;311:1-197.

\section{Submit your next manuscript to BioMed Central} and we will help you at every step:

- We accept pre-submission inquiries

- Our selector tool helps you to find the most relevant journal

- We provide round the clock customer support

- Convenient online submission

- Thorough peer review

- Inclusion in PubMed and all major indexing services

- Maximum visibility for your research

Submit your manuscript at www.biomedcentral.com/submit

) Biomed Central 